\title{
高速ディーゼル機関における燃焼音と NOxへのセタン指数の影響*
}

\author{
長 谷川勝男** 小田健 - ${ }^{* *}$
}

Effects of Cetane Index on Combustion Sound and NOx Emissions of a High Speed Diesel Engine

by Katsuo Hasegawa and Ken'ichi ODA

The increasing rate of engine sound and vibration is a grave problem on the coastal fishing boats. The acoustic characteristics of sound emission were studied with respect to the cetane Indices of fuel using a single cylinder diesel engine. At the same time, NOx emission was evaluated to cetane index correlation. Consequently, levels of combustion sound and NOx emission were increased appreciably at cetane Indexs below 45. These are due largely to the high rate of combustion pressure rise just when the violent pre-mixed combustion caused by long ignition delay occurred.

\section{1. はじめに}

漁船は, 機関をはじめとして多数の振動・騒音源 を有し，さらに船体外部からのプロペラや波浪によ る音も加わり複雑な騒音の環境におかれている. 沿 岸小型漁船では主機関の高速高出力化により騒音は 増大する傾向にある. 乗組員にとっては, 居住区や 労働の場所が主機関に近接せざるをえないことから 騒音問題は深刻な状況にあり, 労働環境の向上のた めにその対策が課題である.

さらに機関の騒音増大要因として, 燃料のA重油 のセタン価（セタン指数）が今後低下することが紫 念されている ${ }^{1)}$. 圧縮着火燃焼を行うディーゼル機 関によって, 着火性の善し悪しの尺度であるセタン 価は, 燃料の重要な性状因子である. セタン価低下 の影響は小型高速機関で特に大きくなることが予想 される.

機関保守の省力化を目的として，音響手法による

\footnotetext{
*原稿受付 平成 5 年 4 月 16 日

平成 4 年秋季学術講演 (平成 4 年11月11日)

$* *$ 正会員 水産工学研究所（茨城県鹿島郡波崎町海老台）
}

異常診断システムに関する研究が盛んに行われてい $ろ^{2)}$. 正常か異常かを判別するためには燃焼音等か ら異常音を精度良く抽出する必要がある. そのため にも燃料性状に起因する燃焼音の特性を解明してお く必要があろう.

すでに著者らは低セタン価然料の機関始動性, 燃 焼特性, 燃焼改善策について報告している ${ }^{3,4)}$. 本 報では直噴式ディーゼル機関を用いて燃料のセタン 指数の低下による燃焼音への影響について調べるこ とにする.一般に漁船に搭載される多気筒機関では 騷音とその発生源との関係の解析は複雑となる.こ こでは単気筒機関を用いて問題を単純化し，ディー ゼル機関の騒音の発生過程および伝播過程を調べる ことも併せて目的とする. また，セタン指数と NOx排出濃度との関係についても検討を加えた.

\section{2. 供試燃料と実験方法}

セタン指数が極端に低い分解軽油と一般の市販軽 油を混合してセタン指数 35 から 600 範囲で供試燃料 油を作製した. 表 1 に分解軽油と軽油の燃料性状を 示す. 分解軽油は芳香族分が多く密度が大きい. セ 
タン指数は密度と50\%留出温度等を用いて計算され るが，現行のJISではASTM D-976（1966）に準 拠した算出法を用いている. ASTMではその後よ り精度の高い算出式に改訂されている.ここでは JIS K 2204のセタン指数計算式による値を採用す ることにする. 比較のためにそれぞれの算出式から 計算したセタン指数を表 1 中に示す.

供試機関の主要諸元を表 2 に示す．振動, 騒音の 計測装置の概略を図 1 に示す．筒内圧力の計測には 歪ゲージ式の指圧変換器を用いた。振動計測には圧 電式加速度ピックアップを用いて，ピストン運動方 向 ( $\mathrm{x}$ 方向) とシリンダライナの法線方向 ( $\mathrm{y}$ 方向) の加速度を計測した. 騒音計測用のマイクロフォン は機関から $1 \mathrm{~m}$ の位置とした。これらの信号は一旦 データデコーダに記録した後, FFTアナライザお よびコンピュータを用いてデー夕解析を行った. 後 述する筒内圧力および騒音の帯域フィル夕処理では データを再生する際に万能分析器（RION SA33D）を用いて $1 / 3$ オクターブバンドのフィルタ リングを行った. 排気ガスの測定にはNOx分析計

\section{表 1 供試燃料油の性状}

\begin{tabular}{|c|c|c|}
\hline 項 目 & 分解軽油 & 市販軽油 \\
\hline 密度 $015^{\circ} \mathrm{C} \mathrm{g} / \mathrm{cm}^{3}$ & 0.931 & 0.836 \\
\hline 引火点 $\quad{ }^{\circ} \mathrm{C}$ & 69 & 63 \\
\hline 粘度 $@ 30^{\circ} \mathrm{C} \mathrm{mm} / \mathrm{s}$ & 3.21 & 4. 16 \\
\hline 10\%残油炭素 wt\% & 0.43 & 0.01 \\
\hline 硫黄分 wt\% & 0.51 & 0.30 \\
\hline 灰 分 $w t \%$ & 0.01 & $<0.01$ \\
\hline 真発熱量 $\mathrm{kJ} / \mathrm{kg}$ & 41900 & 43200 \\
\hline CFPP $\quad{ }^{\circ} \mathrm{C}$ & -17 & -10 \\
\hline \multicolumn{3}{|l|}{ 組成環分析 \% } \\
\hline $\mathrm{C}_{\mathrm{N}}$ & 14.2 & 16.5 \\
\hline $\mathrm{C}_{\mathrm{A}}$ & 52.8 & 22.5 \\
\hline \multicolumn{3}{|l|}{ 分留性状 ${ }^{\circ} \mathrm{C}$} \\
\hline $10 \%$ & 238.0 & 227.0 \\
\hline $50 \%$ & 273.5 & 292.0 \\
\hline $90 \%$ & 321.5 & 352.5 \\
\hline \multicolumn{3}{|l|}{ セタン指数 } \\
\hline $\begin{array}{l}\text { JIS K 2204(1991) } \\
\text { (ASTM D 976(1966) }\end{array}$ & に準拠) & 60.0 \\
\hline ASTM D 976(1980) & 27.4 & 56.7 \\
\hline ASTM D4737(1987) & 25.2 & 61.4 \\
\hline
\end{tabular}

(SHIMADZU NOA-305), CO計 (SHIMADZU CGT-10）を用いた.

機関の運転条件として, 回転数 $1800 \mathrm{rpm}$ 一定の もとで実験を行った. 負荷 $100 \%$ は定格出力時の Pmeと等しくなるように動力計荷重を設定した. 負荷 $100 \%$ の出力は $5.1 \mathrm{~kW}$ である.

\section{3. 結果亡考察}

\section{1 セタン指数亡燃焼解析 セタン指数} 35 から 60 まで 5 刻みで燃料を作製して機関回転数 $1800 \mathrm{rpm}$ 一定のもとでセタン指数の影響を調べた. 図 2 に燃焼状態とセタン指数の関係を示す. 燃料の セタン指数の低下にともない着火遅れは大きくなる が，特に低負荷運転時にその傾向が顕著である．最 高圧力（Pmax）はセタン指数が45以下になると中 ・高負荷時では増大している. 低負荷時ではほぼフ ラットである. 圧力上昇率の最大值 $(\mathrm{dP} / \mathrm{d} \theta \mathrm{max}$ ) は負荷 $100 \%$ ではセタン指数の低下につれて急上昇

\section{表 2 供試機関の主要諸元}

\begin{tabular}{|c|c|}
\hline 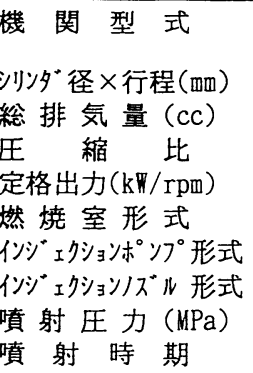 & 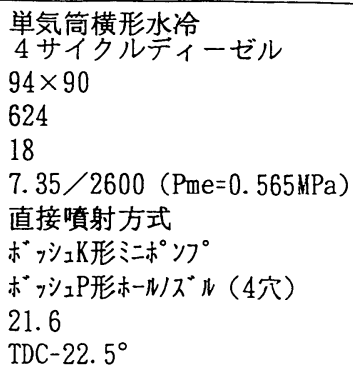 \\
\hline
\end{tabular}

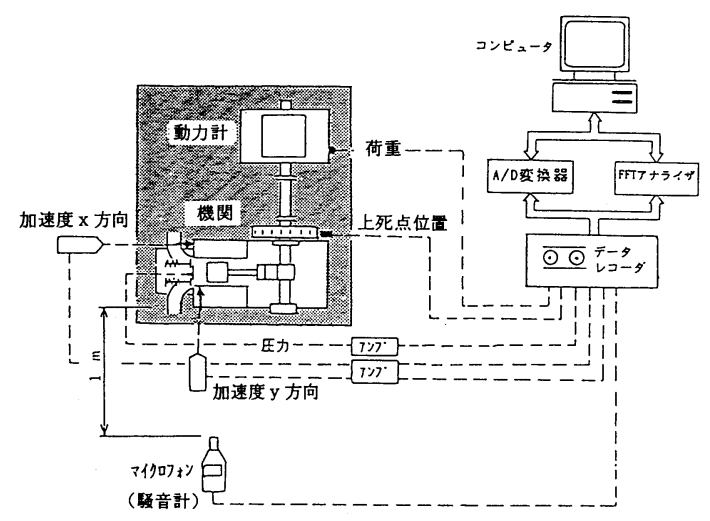

図 1 振動・騒音計測装置 


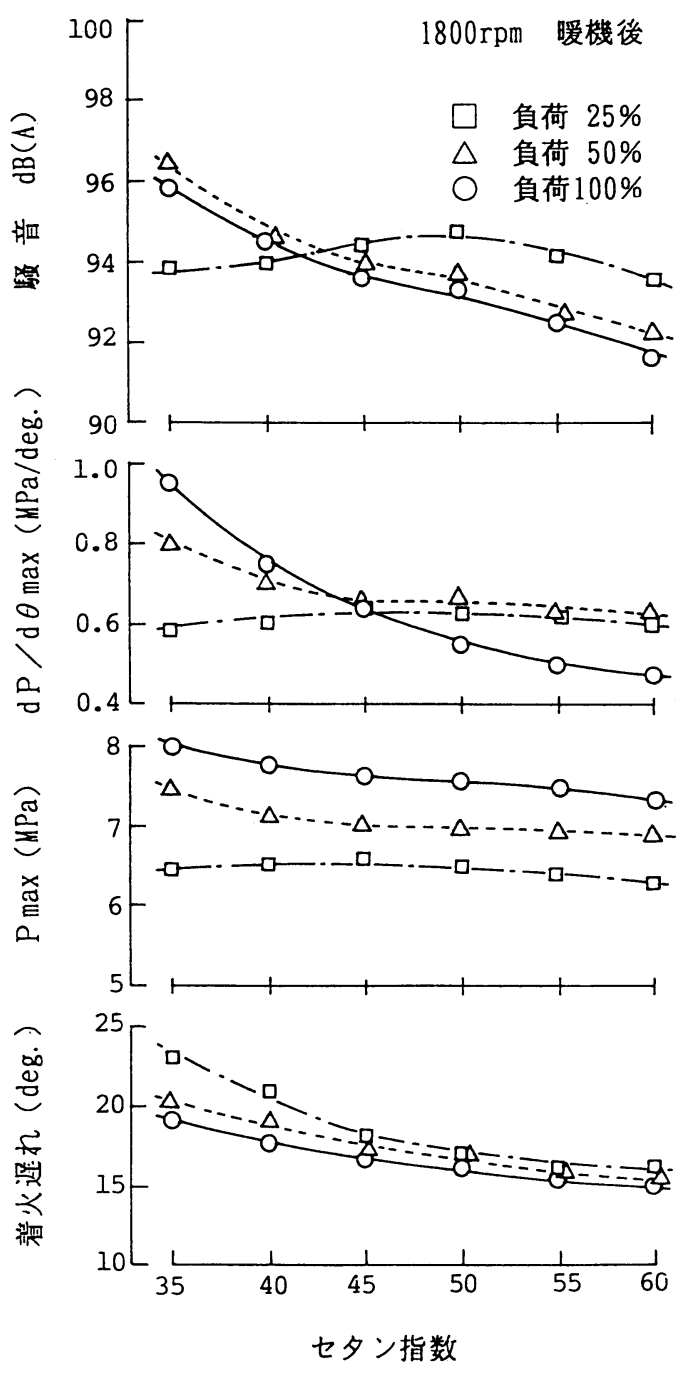

図 2 燃焼状惉とセタン指数の関係
している.これは予混合燃焼が爆発的になったため であり,この筒内圧力の急上昇に誘起されて騒音も 大きくなっている．低セタン指数燃料の燃焼状態は 吸気温度や機関温度に影響される。実験時の室温は

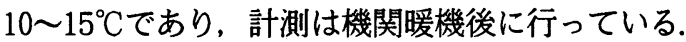

\section{2 振動・騒音の時間波形 筒内圧力,} 加速度之騒音の時間的变化を図 3 に示す．筒内の圧 力変化によって機関か加振され，その結果として音 が放射される過程を示している. セタン指数 60 では 無負荷時と全負荷時の振動，騷音波形の差はそれほ ど顕著ではない，負荷 $100 \%$ のタン指数 40 では急 激な圧力上昇に誘起されて振動, 騒音ともに大きく なる様子がわかる，振動は短時間で咸衰するが，騒 音波形は比較的長時間にわたって振動が継続してい る.なお，騒音波形は機関からマイクロフォンまで の距離 $1 \mathrm{~m}$ の伝達荤れを補正してプロットした。

\section{3 筒内圧之騒音の周波数解析 前述し} たように燃焼騒音は燃焼による圧力急上昇を加振力 として機関表面から放射される音である. 従って燃 焼騒音は筒内の圧力経過と密接に関係する，そこで FFTアナライザを用いて図 3 に示した筒内圧力と 騒音波形の周波数解析を行った．図 4 は筒内圧の周 波数特性を示し, 図 5 は騒音の周波数特性である. いずれもセタン指数 40 と 60 を比較している．燃料の セタン指数の低下によって筒内圧，騒音ともに音圧 レベルが高くなっている．特に $500 \mathrm{~Hz} ら 5 \mathrm{kHz}$ 周波数帯で明確に差がみられる.

一般に構造物か加振されると, 加振力の周波数成 分に応じて構造物固有のインピーダンスで振動応答 し，外表面から固有の周波数スペクトルを持った音 が放射される. 機関での音の伝播伝達系においては,

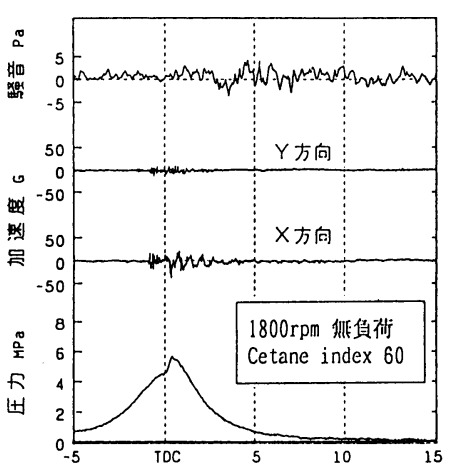

時間 $\mathrm{msec}$

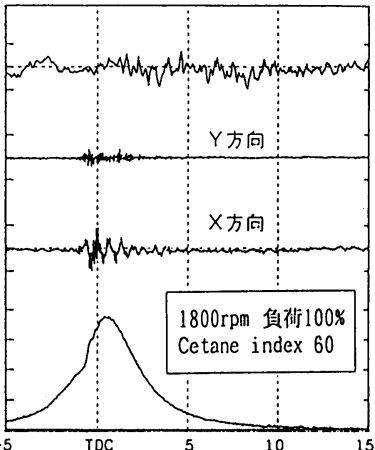

時間 msec

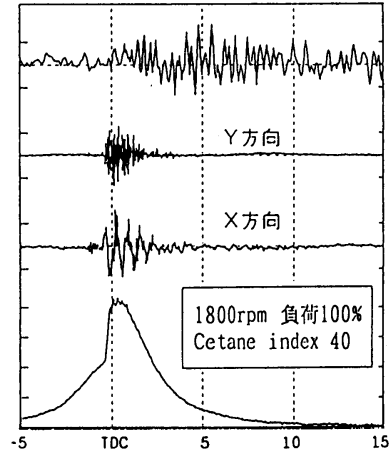

時間 $\mathrm{msec}$

図 3 振動・騒音の時間波形 
筒内の音圧はシリンダライナやクランクケースなど の機関構造体により減衰されて外部へ音が放射され る.この減衰特性は, 図 4 で示した筒内圧のスペク トルと図 5 で示した騒音のスペクトルの差で評価で きる. 条件の異なる 3 例の減衰特性を図 6 に示す. それぞれ $1 \mathrm{kHz} \sim 3 \mathrm{kHz}$ 帯を底とするV字形の線図 となる.この減衰特性は回転速度や負荷などによら ず常に一定のもので機関固有の性質である ${ }^{5,6)}$. 機 関構造をフィルタとしてとらえると周波数 $1 \mathrm{kHz}$ $3 \mathrm{kHz}$ 帯の音が最も通り易いことを示している. 図 4, 図 5 で示したように筒内音, 騒音がセタン指数 の低下によって増大する周波数域は $500 \mathrm{~Hz} \sim 5 \mathrm{kHz}$ であり，これは減衰特性が最低となる周波数帯と良 く一致している. また, 人の聴感度の高い周波数帯 $(300 \mathrm{~Hz} \sim 6 \mathrm{kHz})$ とも一致することになる.

\section{4 筒内圧亡騒音の帯域フィルタ処理}

筒内圧力波, 騒音波を特定周波数帯だけを通過さ せるフィルタを通し，クランク角度に対するプロッ
トを行えば周波数別の音波の時間波形を得ることが できる.このような限定された周波数帯の時間波形 は音の発生・伝播メカニズムの理解の助けとなる. また音響手法を用いた機関の異常診断システムにお いても, 特定の周波数帯を抽出して解析できるので 検出感度を高めるのに有効な方法となる.

図 7 にセタン指数600場合の 4 サイクル分のクラ ンク角度に対する筒内音と騒音をそれぞれ帯域フィ ル夕処理した例を示す. 図 8 はセタン指数40の場合 の結果である. なお, 帯域フィルタとして $1 / 3$ オ クターブバンドを設定した. 図中に示す中心周波数 はこの $1 / 3$ オクターブバンドの中心の周波数である.

筒内圧力波を帯域フィルタ処理した線図より次の ことがわかる. 燃焼に伴って筒内では圧力振動が激 しくなっている. 中心周波数が $1 \mathrm{kHz}$ 以上では燃焼 開始点に漸近する減衰振動がみられる.上死点後の ピストン下降に伴って, 圧力振動は低周波数域に移 行している. 中心周波数 $200 \mathrm{~Hz}$ では上死点後 90 度あ

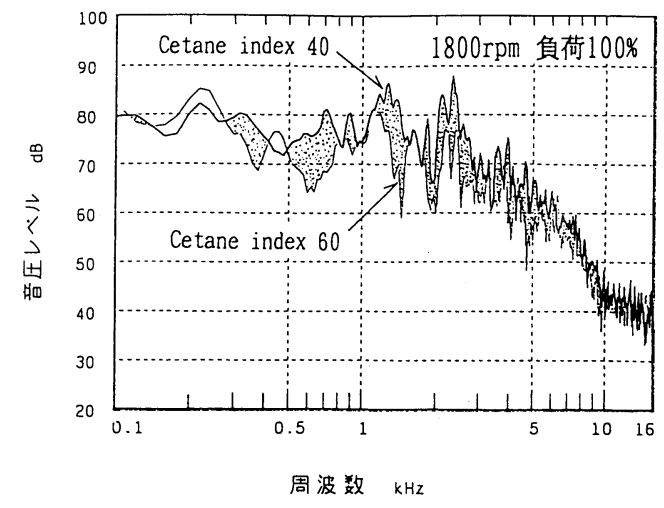

図 5 騷音の周波数特性

図 4 筒内圧の周波数特性

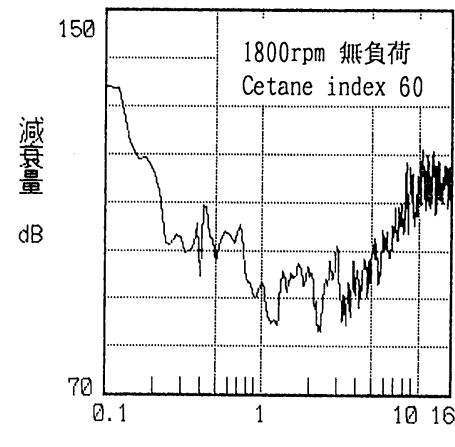

周波数 $\mathrm{kHz}$

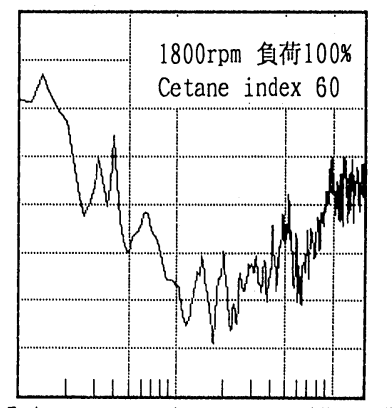

$10 \quad 16 \quad 0.1$

周波数 $\mathrm{kHz}$

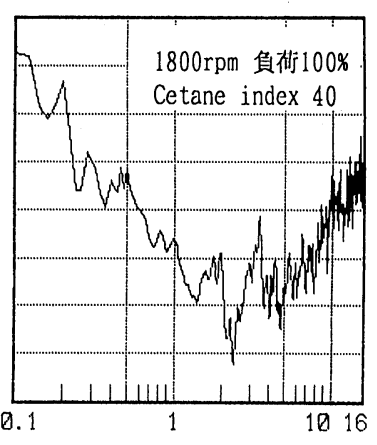

周波数 $\mathrm{kHz}$

\section{図 6 機関の構造減衰特性}


たりで振幅が最大になっている。これらの傾向はセ タン指数40でも同様であることがわかる. しかし, 同一周波数の圧力振動の振幅を比較する之, セタン 指数40の方が大きくなっていることから, セタン指 数の低下によって筒内の圧力振動がより激しくなっ ている.

騒音波形では，各周波数成分とも燃焼行程で大き な振動がみられる．図中のALL PASSの波形はマ イクロフォンに入る原音を示している．騒音波形は その発生源が多岐にわかるため筒内音に比べて複雑 であるが，周波数が高くなるに従い最大振幅の位置 は着火点に漸近してくる傾向がみられる. セタン指 数60と40の線図を比較すると, セ夕ン指数40の方が 全周波数域で音の振動が大きくなっている. 特に周 波数 $2 \mathrm{kHz}$ と $3.15 \mathrm{kHz}$ で顕著である.なお，騒音の 波形は機関からマイクロフォンまでの距離 $1 \mathrm{~m}$ の伝 達遅れを補正して表示した。

図 7 と図 8 の比較から, セタン指数の低下によっ て騒音が大きくなるのは，燃焼音の寄与が大きいこ

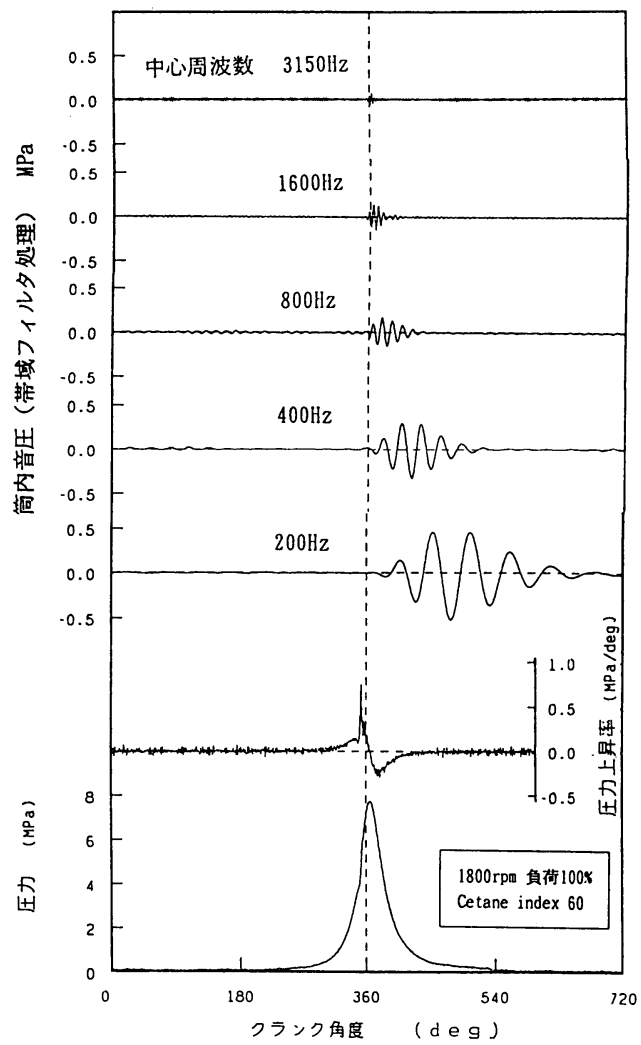

とがわかる.

3.5 セタン指数とNOx濃度 すでに述べ てきたように, 燃料のセタン指数の低下は予混合燃 焼を活発化させる．それはサーマルNOx生成を促 進させる要因となる．ここでは排気ガス組成に対す るセタン指数の影響について検討する.

図 9 にNOx濃度, CO濃度とセタン指数の関係を 示す. 高負荷時にはセタン指数の低下にともない NOx濃度は上昇している. 一方, 低負荷時ではセ タン指数の低下につれてNOx濃度は減少傾向にあ るが, CO濃度は急激に増加している．次に燃焼波 形からこれらの結果を考察する.

図10は負荷 $25 \%$ におりるタン指数 $60 ， 45 ， 37$ の 燃焼波形を比較したものである．同様に図11には負 荷 100\%時の燃焼波形を示す．負荷 $25 \%$ ではセタン 指数の低下によって着火遅れが大きくなっている. 負荷 $100 \%$ 時には着火時期はセタン指数によってそ れほど大きくは違わないが, 熱発生率の最大値には 顕著な差がみられる.

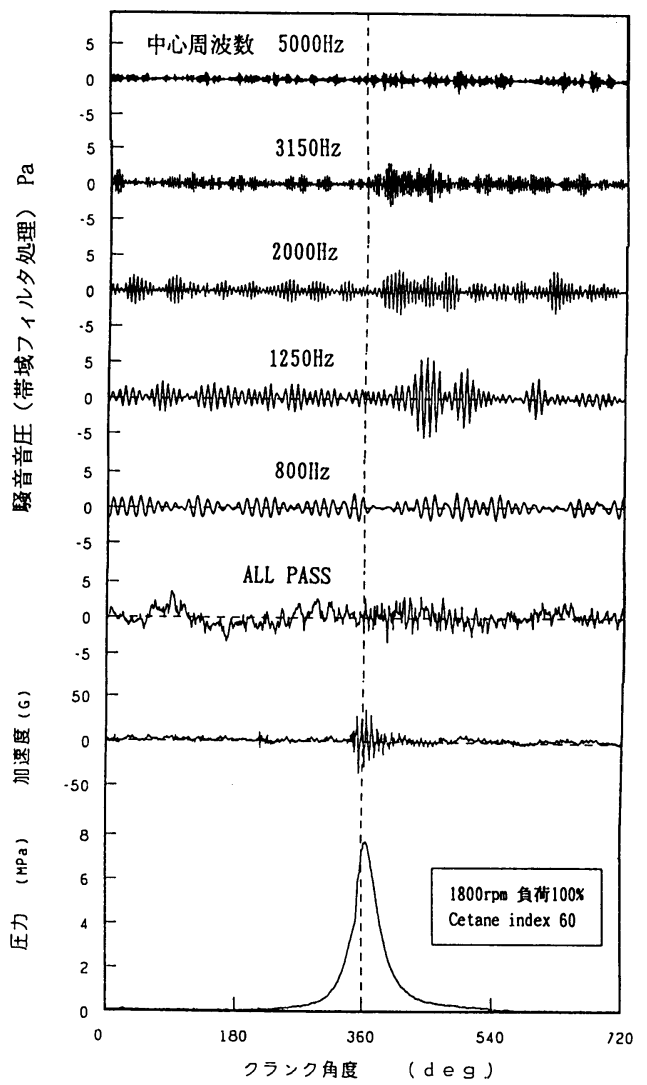

図 7 筒内圧, 騒音の周波数解析（負荷 $100 \%$, セタン指数60） 


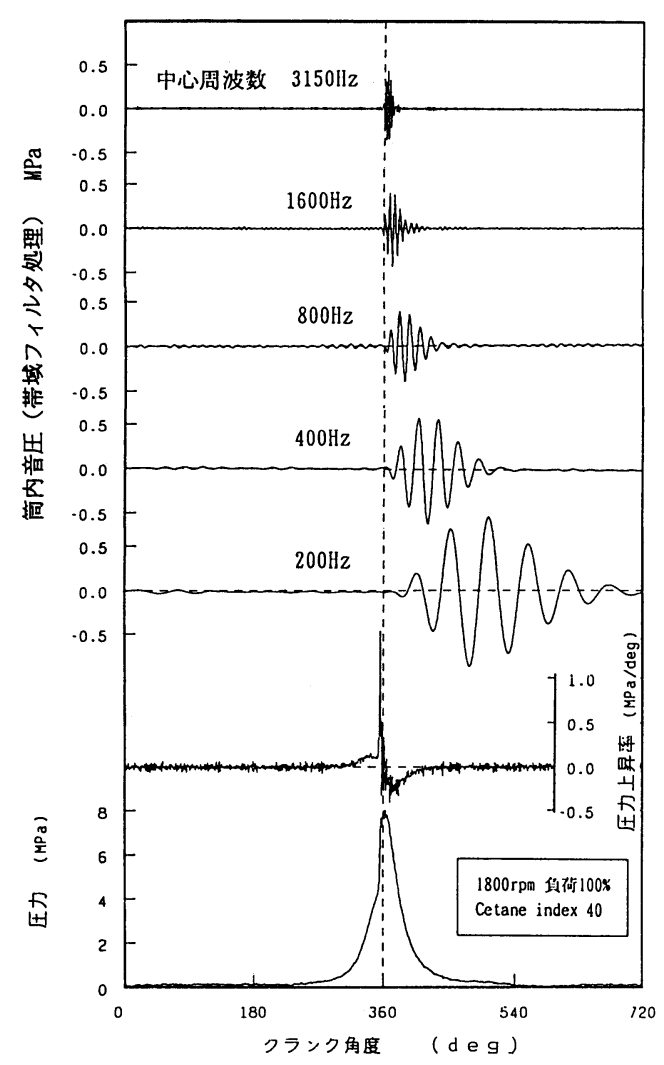

図 8 筒内圧, 騒音の周波数解析

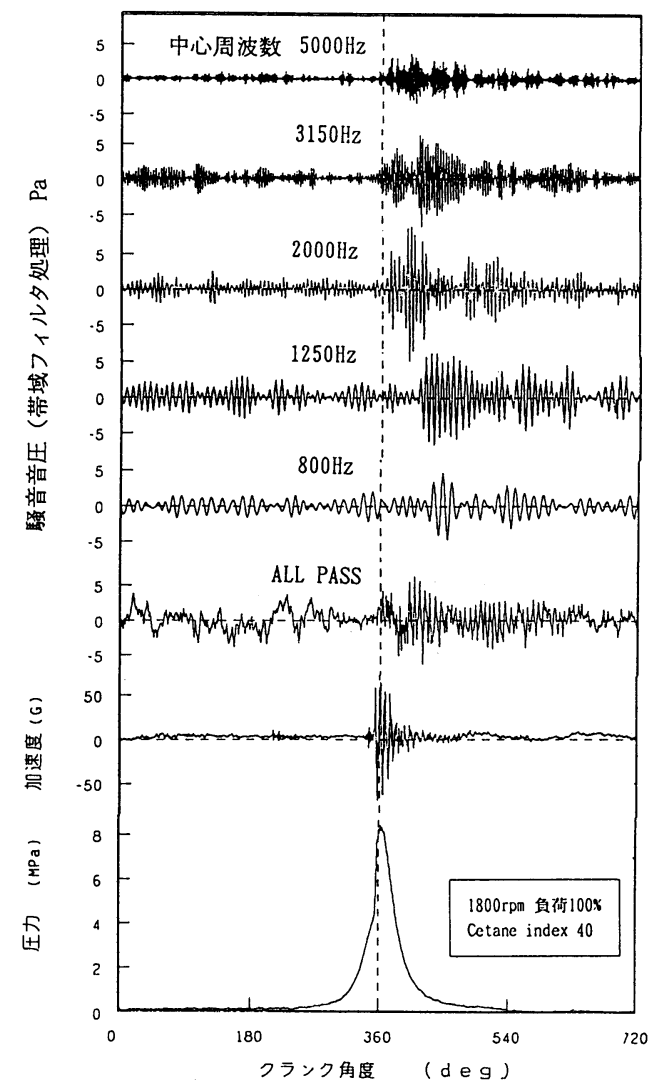

（負荷 $100 \%$ ，セタン指数 40 )
低負荷時では, セタン指数が低くなると上死点付 近の圧力, 筒内温度とも低く抑えられるためにサー マルNOxの生成が抑制された反面，不完全燃焼生 成物であるCOの排出が増加したもの之考えられる. 高負荷時では, セタン指数の低下にともなって圧力 上昇が急激となり，ちょうど上死点付近で熱発生が 最大となっているために，サーマルNOxの生成が 促進されたものと考えられる.これらの結果から $\mathrm{NOx}$ 生成条件として予混合燃焼の激しさ, 即ち上 死点直後の圧力, 燃焼温度が大きな意味を持つこと がわかる.

\section{4. ま と め}

以上のように燃料のセタン指数が必要以上に低下 すると予混合燃焼が激しくなる結果，燃焼に伴う振 動・騒音が増大するほか排気ガス組成にも大きな影 響を与えることがわかった.

燃焼音の音響解析より，セタン指数低下による騒
音の増加は燃焼音の寄与が大きく, $500 \mathrm{~Hz}$ から 5 $\mathrm{kHz}$ の周波数領域で顕著であった。 また，機関の構 造減衰特性はセタン指数や負荷などの条件に無関係 であった.

燃料のセタン指数の実用上のボーダーラインに関 しては，気筒容積，圧縮比，機関回転数，燃焼室形 式などの条件, さらに吸気温度とも関係し一概には 決められないが，冬期でも機関の始動を保証できる 值は最低限必要となる．また，リング・ライナの摩 耗など耐久性面の検討も今後の課題となろう。

\section{文献}

1 ) 花島 : A重油のセタン価の動向, 漁船機関, 793 (19 92-11) 796 (1993-2)

2 ）例えば片木ほか: 舶用ディーゼル機関の診断技術に 関する研究，舶機誌，21-6 (1986-6)，360

3 ) 小田ほか: 小形ディーゼル機関による低セタン指数 燃料の燃焼，舶機誌， 24-6 (1989-6)，177 


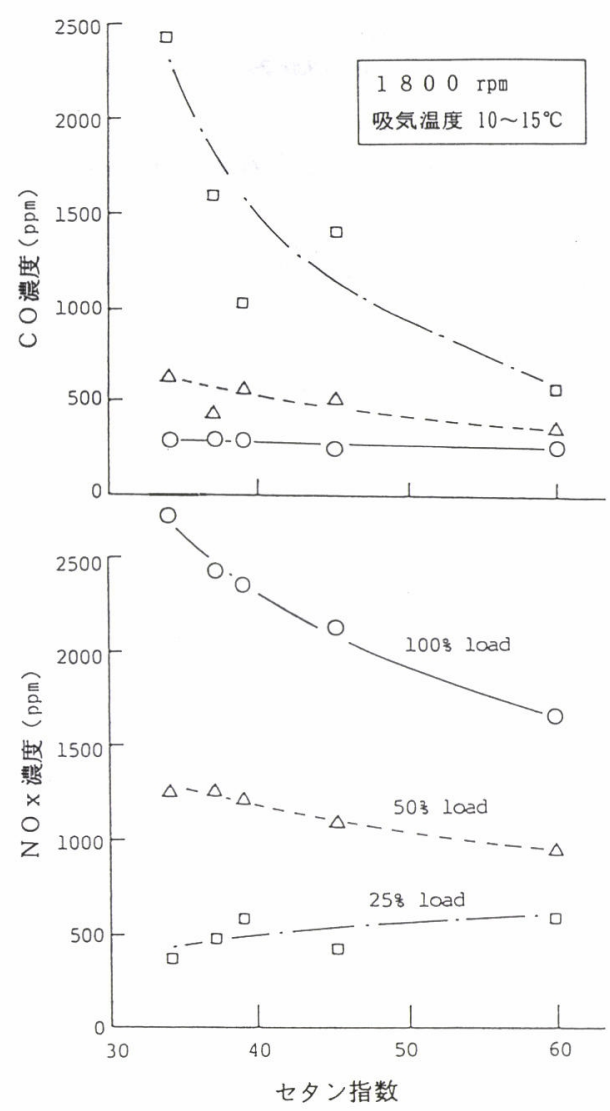

図 9 セタン指数よ排気ガスの関係

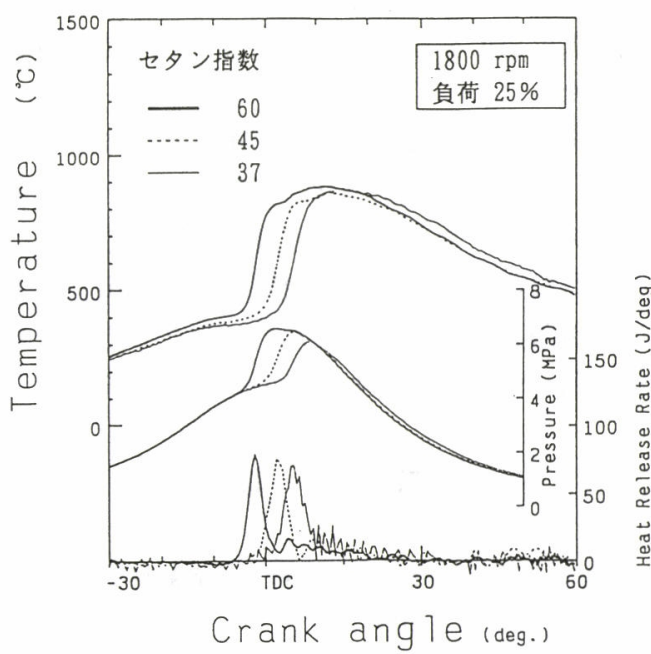

図10 低負荷運転時の燃焼波形

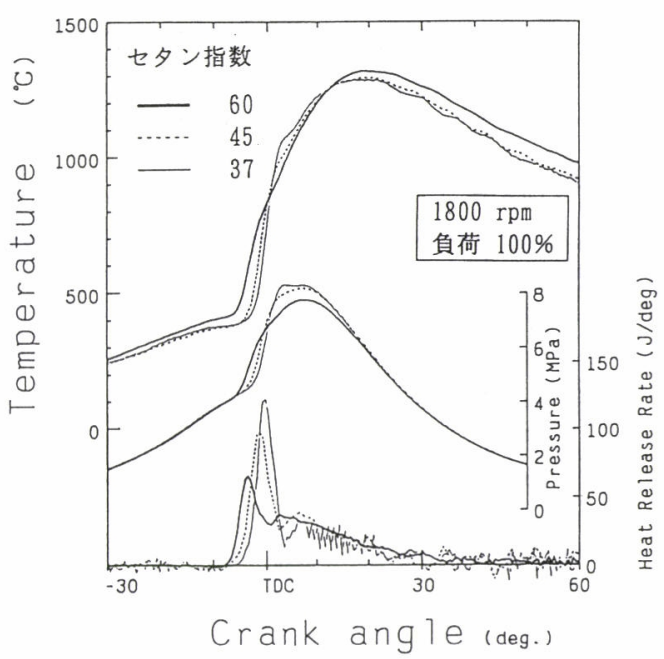

\section{図11 高負荷運転時の燃焼波形}

4 ) 長谷川ほか：小型機関における低セタン価燃料の燃 焼特性，水工研研報，12（1991-3），61

5 ) 米澤ほか：ディーゼル機関における燃焼騒音予測手 法, 舶機誌, 25-1 (1990-1)， 5

6 ) 岡村: エンジン騒音とそのシミュレーション, 舶機 誌, 25-9 (1990-9) , 605

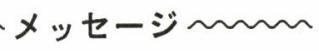

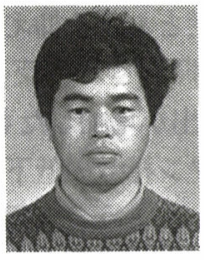

長 谷川勝男

本報では音の問題を中心に展開しました，騒音は不快な音 ですので音圧の低減が焦点になります。しかし，音はたくさ んの周波数成分から構成されており，情報の集まりであると も考えられます．この貴重な情報をいかに有効利用するかが 今後の課題となります. また，人の感性に合わせるように音 を改質させる研究も必要と思います. 